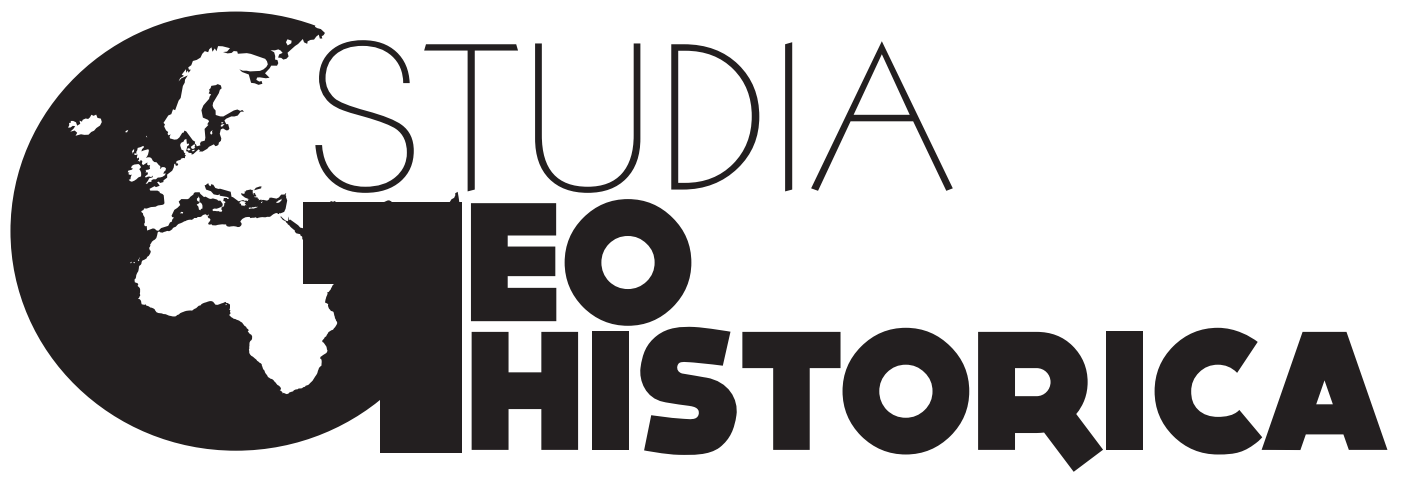

NR 06|2018 ROCZNIK HISTORYCZNO-GEOGRAFICZNY 


\section{Contents}

A note from the editors 5

International Conference of Historical Geographers

Diogo de Carvalho Cabral

Landscape and Letterscape in Early Colonial Brazil 7

Karen M. Morin

Prisoners and Animals: An Historical Carceral Geography ... 28

Humphrey Southall

Spaces, Places, Features and Units: Web-Enabling Historical Geography. 39

\section{Articles and theses}

Agnieszka Latocha, Dominik Nowakowski

Sources and Methods Used in the Reconstruction of Settlement Networks:

An Archaeological and Geographical Perspective on the Example of Silesia

Marek Sobczyński

Polish Geographical Survey of Borders until 1945

\section{Roman Czaja}

Historical Atlas of Polish Towns. Between Source Edition

and the Cartographic Presentation of Research on the History of Towns

\section{Piotr Guzowski}

Economic Geography of Poland in the Period of Growth (14-16th Century)

in the Polish Historical Study

Dzmitry Vitsko

Historical Cartography in Belarus (Studies on the Administrative Division,

Borders and Population of the Grand Duchy of Lithuania)

Henryk Rutkowski

A Few Comments on the Historical Borders in Poland

Bogumił Szady

Historical Cartography of Confessions and Religions in the Polish-Lithuanian

Commonwealth: Between Historical Geography and Spatial History 136 


\section{Tomasz Figlus}

The Past and Present of Historical Morphology of Rural and Urban Forms in Poland

\section{Maryana Dolynska}

Some Principles of Interdisciplinary Investigation

for Recreating the Historical Topography of Urban Spaces

\section{Atlas Fontium}

Atlas Fontium

(Marek Stoń)

Tomasz Panecki, Tomasz Związek, Grzegorz Myrda

The Spatial Database Development for Research on Settlements and Afforestation in Nowy Tomyśl Plain in Early Modern Times

Marek Słoń, Urszula Zachara-Związek (eds.)

The Court Records of Wschowa (1495-1526). Digital Edition

\section{Reviews and discussions}

Deutscher Historischer Städteatlas, Nr. 5: Dortmund, Hrsg. Peter Johanek, Jürgen Lafrenz, Thomas Tippach, Münster 2018 (Michał Stomski) 


\title{
Some Principles of Interdisciplinary Investigation for Recreating the Historical Topography of Urban Spaces
}

\author{
Maryana Dolynska
}

The studies of the sources on the location of some buildings or real estates in the late $20^{\text {th }}$ century showed that there were no publications about the Lviv territory development, nor were there any investigations of methods in the explorations in historical topography.

The aim of this article is to demonstrate the author's method of the historical topography of urban spaces recreation. While this method was elaborated by the author, its application should incorporate some interdisciplinary sources and methods, including separate methods of historical geography and historical cartography.

The results of the long-term research were published in numerous articles and books. They have demonstrated the various steps of the method ${ }^{1}$, the usage of manuscripts ${ }^{2}$, the employment of interdisciplinary investigations and sources, such as historical cartography ${ }^{3}$ and urbanonymy $y^{4}$.

1 М. Долинська, Ретроспективна метода дослідження забудови середмістя Львова, in: Урбаністично-архітектурні проблеми міст Галичини. Збірник наукових праць, ред. Г. Петришин еt al., Львів 1998, р. 56-62; eadem, "Вступ до соціотопографіі" як узагальнений метод історико-архівних попередніх досліджень в реставрації архітектурних об'єктів, "Вісник Державного університету џЛьвівська політехнікак. Архітектура", 429, 2001, p. 166-173; eadem, Ретроспективна топографія містечка Кути: метод дослідження, конскрипційний та етнічний аналіз, in: Дрогобицький краєзнавчий збірник, вип. 6, Дрогобич 2002, р. 259-268; eadem, До проблеми складових та джерел соціотопограсії, in: Дрогобицький краєзнавчий збірник, вип. 7, Дрогобич 2003, р. 420-433.

2 М. Долинська, О. Мельник, Методика використання журналів обліку XIX ст. для локалізації нерухомості в Галичині, "Вісник Національного університету »Львівська політехнікащ. Архітектура", 410, 2000, р. 362 363; М. Долинська, Йосифінська метрика, як джерело для вивчення території львівських передмість, Семінарій "Княжі часи". Давній Львів, 1,2003, p. 47-54.

3 Eadem, Елементи картографічного методу дослідження у вступі до соціотопографії, in: Історичне картознавство України. Збірник наукових праць, ред. Я. Дашкевич еt аІ., Львів-Київ-Нью-Йорк 2004, р. 44-55.

4 Eadem, Гороніми на територіях колишніх міських сіл Львова, in: Дрогобицький краєзнавчий збірник, вип. 8, Дрогобич 2004, р. 229-235; eadem, Гороніми історичних передмість Львова кінця XVIII-початку ХХст., "Вісник Львівського університету. Серія історична", 39-40, 2005,
Some articles ${ }^{5}$ and books ${ }^{6}$ show the outcome of this research.

\section{Topographical Background}

Different interpretations of the historical and social topography have a common subject of analysis, namely the study of the connections between the social structure and the urban space ${ }^{7}$. Therefore, such a method means placing the social structure on historical maps $s^{8}$. That is why social topography (as a method, or as a scientific branch) must utilize the methods and analysis of historical sources, historical cartography, iconography, metrology, and architectural archaeology.

The social topographical research enables a comparison of fiscal or statistical sources with old town maps?. Such analysis was done for the Late Medieval Age in many cases. Scholars used old town

р. 413-429; eadem, "Вулиці" львівських передмість у фіскальник документах останньої третини XVIII ст., "Записки НТШ. Праці секції спеціальних (допоміжних) історичних дисциплін", 152, 2006, р. 98-102.

5 Eadem, Соціотопографічна характеристика Української (Руської) дільниці Львова у XVI-XVIII ст. Загальні уваги, іn: До джерел. Збірник наукових праць на пошану Олега Купчинського з нагоди його 70-річчя, т. 1, ред. І. Гирич et al., Київ-Львів 2004, р. 766-780; eadem, Історична топограффія нерухомої власності містечка Кути (основні точки, шлях обходу), "Народознавчі зошити", 1-2, 2004, р. 563-581; eadem, Історична топографія самоврядних передмість міста Львова XVI-XVIII ст., in: Дрогобицький краєзнавчий збірник, вип. 9, Дрогобич 2004, р. 214-224; eadem, Пам'ятник Королю Данилу в контексті історичної топографії Львова, "Пам'ятки України", 1, 2005, р. 132-139.

6 Eadem, Історична топограсрія Львова XIV-XIX ст., Львів 2006; eadem, Теоретична реконструкція історичної топографії містечка (на прикладі смт. Кути), Львів 2007; eadem, Львів: простір на тлі мешканців XIIIXIX Ст., Львів 2015.

7 M. Goliński, Socjotopografia późnośredniowiecznego Wroctawia, "Acta Universitatis Wratislaviensis. Historia", 134, 1997, p. 274.

8 Я.Р. Дашкевич, Социотопография городов как направление историко-краеведческих исследований, in: Тезисы докладов и сообщений. Первая всесоюзная научная конференция по историческому краеведению, отв. ред. С.С. Хромов, Полтава 1987.

9 J. Wiesiołowski, Socjotopografia późnośredniowiecznego Poznania, Poznań 1997. 
maps ${ }^{10}$, which are younger by a couple of centuries than the fiscal and statistical sources ${ }^{11}$. Thus, historians do not declare the method of obtaining historical sketches and proclaim that social topographical investigations are impossible to do due to there not being contemporary maps of towns in the Late Medieval Age ${ }^{12}$. When there are often only late $17^{\text {th }}-18^{\text {th }}$ century original maps for the majority of East-Central European lands; the scholar creates a hypothetical map based on manuscript data. The manuscripts and the methodologies needed for scholars to create such a historical map shall be examined in this paper through the example of Lviv and the neighbouring towns within the region.

Contemporary Lviv is a large city in the Western part of Ukraine. The ancient town of Lviv was founded as the capital of the Halytsko-Volynska state by Kniaz ('Duke') Lev and his father King Danylo in the middle of the $13^{\text {th }}$ century. After the war between the Kyiv-Rus principalities and the Mongols, this state was occupied by neighboring kingdoms. The Polish Kingdom, the Hungarian Kingdom and The Grand Duchy of Lithuania, were all, at one time or another, rulers of Lviv since the middle of the $14^{\text {th }}$ until the late $14^{\text {th }}$ century.

The land of Western Ukraine was under Polish rule from the late $14^{\text {th }}$ century until 1772. In 1569 Poland and Lithuania united as a Commonwealth and Lviv became a part of this Commonwealth until 1772, when the Austrian Monarchy occupied that area of the Polish-Lithuanian Commonwealth. Subsequently, Lviv came under the Austrian rule until 1918.

10 A. Tomczak, Źródła kartograficzne do dziejów Torunia z przełomu XVIII i XIX w., "Acta Universitatis Nicolai Copernici. Nauki Humanistyczno-Spoteczne. Historia", 9, 1973, p. 175-183.

11 T. Jasiński, Próba nowego spojzzenia na toruńskie księgi szosu, in: Studia nad dziejami miast i mieszczaństwa w średniowieczu, t. 2, Torun 1996 (Studia Polonica Historiae Urbanae, 2), p. 133-139.

12 R. Czaja, Socjotopografia miasta Elblaga w średniowieczu, Toruń 1992 p. 9.
There was a brief period of a year and a half of independence for the Western Ukrainian People's Republic. After that, it changed hands between numerous occupants: the Polish, the Soviets, the German, and, once again, the Soviets until 1991.

Some of these dependences had significant influence on the spatial structure of Lviv. The structure of the town was similar to other Central or Western European towns: a castle (castrum, burg, grad, dytynets) and an extensive settlement (po$d i l)$, the latter having no fortifications and were inhabited by merchants and craftsmen. Around the early 1270s the features of spatial organization, defined by legal regulations (town law of Magdeburg), began to appear in Lviv. The primary Lviv space of the $13^{\text {th }}$ century was based on the real estate of the first Lviv advocatus, Bertold Stecher, and the laneus ${ }^{13}$ area of the St. Mary of the Snows church.

The German family Stecher received land from Duke Lev without being subject to any rent. This real estate consisted of three parts; the villa ('a house in the countryside'); allod ('the land owned and not subject to any rent'); and the molendinum ('mill'). Originally, the St. Mary of the Snow church laneus was near the Stecher mill and this laneus divided the Duke's jurisdiction from the Stecher settlement. All these real estate parts constituted the spatial core of the town under the Magdeburg rights ${ }^{14}$.

\footnotetext{
13 Laneus - medieval measure of area.

14 The discussion about the time when the Magdeburg law was granted in Lviv deserves a separate publication. At least, the problem of spatial location of the German citizens is solved. М. Капраль, М. Долинська, Процес локації міста Львова на магдебурзькому праві у XIII-XIV ст., in: Атлас українських історичних міст, т. 1: Львів, ред. М. Капраль, Київ 2014, р. 21-25; М. Долинська, Елементи локації Львова у княжу добу, "Записки НТШ. Праці комісії архітектури і містобудування", 255, 2008, р. 78-85; eadem, Нерухомість німецької родини Штехерів в пізньосередньовічному Львові: традиційний та інтердисциплінарний погляд, in: Матеріали міжнародної наукової конференції "Феномен мультикультурностів історіїУкраїни іПольщі", Харків 2016, р. 87-93; eadem, Формування ірозвиток території Львова: зміни адміністративно-територіального поділу міста в XIII-XXI століттях, in: Львів: місто - суспіль-
} 
Magdeburg Law was granted a second time in 1356 and its spatial evolution lasted until 1607. During that period, the town space was divided into three typical areas: the 'town within the walls', two suburbs, and villages of the town. Those areas were separated from each other and from foreign territory by the established borders. The landscape of suburbs and villages was very similar to the countryside.

Establishing a clearer understanding and picture of the spatial organisation of the Magdeburg period in Lviv was achieved through a retrospective comparison of manuscripts, which was applied to $18^{\text {th }}$ century maps, as well as taking advantage of pictures and names of real estates, streets, rivers, hills, etc. of the period. I have proposed to name this part of the methodology: the method of the retrospective recreation of real estate locations and the method of recreating historical topography.

\section{Methods and Sources of Historical Topography}

Historical topography and its methods are similar to the methods and subjects of historical geography. This means that a scholar has to put historical data on a map scheme. The main task of historical geography is to portray or illustrate historical phenomena upon a map, and thus generate a picture of the landscape changes and of the correlation between the historical period and the landscape ${ }^{15}$. Such a method of historical geography can be termed the macro-level of historical topography ${ }^{16}$.

Both historical geography and historical topography use data from manuscripts

ство-культура: Збірник наукових праць, т. 10: Львів / Lwów / Lemberg як міськіпростори: уявлення, досвіди, практики, ред. О. Аркуша, О. Вінниченко, М. Мудрий, Львів 2016, р. 13-30.

15 J. Kašpar, Geografická metoda a kartografická metoda v historikově práci (Př́spěvek terminologický), "Historická geografie", 24, 1985, p. 214218.

16 As compared with: Я.Р. Дашкевич, Социотопография; М. Долинська, Історична топографія, р. 36-61. (written sources), cartography, iconography, toponymy / urbanonymy, and then use different methodological approaches that developed during the $20^{\text {th }}$-early $21^{\text {st }}$ centuries at the intersection of historical, social and IT sciences.

\subsection{Manuscripts}

The majority of manuscripts for Lviv concern the pre-statistical sources, such as $14^{\text {th }}-18^{\text {th }}$ century registers of real estate from the walled town centre and suburbs. Different researchers use the following as key sources: records of $s \operatorname{cots}^{17}$, rents and poundage, the lists of the names of dwellers ${ }^{18}$ (this group of serial sources are the most valuable for getting a picture of social life in a Late Medieval or Early Modern town/ city); testament books ${ }^{19}$; church books of the cross (births), marriage and death registers $^{20}$, lists of town - government members, the oldest town's books ${ }^{21}$ and lists of the military taxes ${ }^{22}$.

The best written sources for starting a retrospective exploration of real estate locations date back to the late $18^{\text {th }}$ century Registers of immovable private property, which detail households and their owners for each one of the Austrian towns and villages, including those of Western

\footnotetext{
17 Scots - the medieval registers of real estates.

18 J. Wiesiołowski, Sołacz średniowieczny i staropolski, "Kronika Miasta Poznania", 3, 1999, p. 37; A. Czacharowski, Ze studiów nad strukturą spoteczną mieszczaństwa toruńskiego na przełomie XIVIXV w., "Acta Universitatis Nicolai Copernici. Nauki Humanistyczno-Społeczne. Historia", 9 , 1973, p. 89-91; idem, Sociotopography of Medieval and Late-Medieval Towns in the North-European Zone as exemplified by Torun, "Acta Poloniae Historica", 34, 1976, p. 121-129; T. Jasiński, Toruńskie księgi szosu, p. 133-134.

19 U. Sowina, Najstarsze sieradzkie testamenty mieszczańskie z początku XVI wieku. Analiza źródłoznawcza, "Kwartalnik Historii Kultury Materialnej", 1, 1991, p. 13-25.

20 A. Klonder (rev.), Helga Schultz, Berlin 1650-1800. Sozialgeschichte einer Residenz, "Kwartalnik Historii Kultury Materialnej", 1, 1991, p. 68.

21 J. Wiesiołowski, Poznański katalog rajców dożywotnych z początku wieku XVI, in: Homines et societas. Czasy Piastów i Jagiellonów, ed. J. Bieniak et al., Poznań 1997 (Prace Komisji Historycznej. Poznańskie Towarzystwo Przyjaciół Nauk, 55), p. 513-519.

22 A. Czacharowski, Zagadnienia socjotopografii późnośredniowiecznego Torunia, in: Miasta doby feudalnej w Europie Środkowo-Wschodniej. Przemiany społeczne a układy przestrzenne, ed. A. Gieysztor, T. Rosłanowski, Warszawa-Poznań-Toruń 1976, p. 143.
} 
Ukraine $^{23}$. The administration of the Austrian Monarchy made a list of immovable private property for the entire state. The process of taking the census for the land of Galicia (Königsreich Galizien und Lodomerien) started immediately after this land was incorporated to the Austrian Monarchy. Therefore, there are two types of registers. The first type was composed during the late 1770s-1780s. This set of the register is named the Josephine Cadastre by King Joseph I. The next census of immovable property was carried out in the middle of the first half of the $19^{\text {th }}$ century during the reign of King Franz I. For this reason, the latter set was named the Franciscan Cadastre.

The structure of the notes of Cadastres is as follows: the topographical number; the name of the house, the property owner and the house number (so-called: conscription number), as well as the plot size, the type of plot, and the amount of tax. The conscription numbers were not equal to the topographical numbers since the conscription numbers were assigned only to buildings. There are a lot of auxiliary entries in the register about some settlements, which described the location of sites clearly for the people of that time, for example cemeteries, churches, roads to the surrounding villages and distant towns, rivers and springs, and hills. Natural objects, areas without buildings, roads and streets were not assigned conscription numbers.

The conscription numbers changed from the time of the Josephine to the Franciscan Cadastre, but the topographical numbers were coordinated with each other in both. Some of the late $19^{\text {th }}$ century city guidebooks had the tables of transfer between the conscription numbers and contemporary addresses (the number of the home and street), so we can find the

\footnotetext{
23 Йосифінська (1785-1788) і францисканська (1819-1820) метрики. Перші поземельні кадастри Галичини. Покажчик населених пунктів, ред. П. Захарчишина, Київ 1965, р. 17-344.
}

exact places (on a micro-level) of most late $18^{\text {th }}$ century buildings (fig. 1) But there are no sources from the late $19^{\text {th }}$ to early $20^{\text {th }}$ centuries for small towns and villages. In this case, researchers are forced to reconstruct the way the town clerk who filled in the register (or another fiscal document) might have thought or acted in order to understand the logic of his explication.

The next step is the necessity to find the connection between the conscription numbers and the older traditional household names in order to establish the correct location. The scholar must work with a group of early modern serial sources, which describe many contemporary buildings or real estates. The household rent registers, especially registers of $e l^{4}$, rent are valuable testimonials of Lviv, since in the last known ell register of 1768, traditional household names coexist with the conscription numbers. In this way, matching household names with conscription numbers is possible for the late $16^{\text {th }}-18^{\text {th }}$ centuries, the time when household names were similar to their former or contemporary owners. To recreate the earlier household location it is thus possible to use a mix of historical topography and historical toponymy (urbanonymy). This method works very well in cases that have notes about buildings (palaces, mills, etc). For example, in the early $20^{\text {th }}$ century there was a mill with the address 13 Młynarska St. The Franciscan conscription number was 588 , and the Josephine number was 195 . The property was under the ownership of the Kapitula according to this cadastre. The registers allow the changes of this mill's names (Kapituła Canonics - Stecher - Schilzikut) to be traced from the late $18^{\text {th }}$ century back to the late $13^{\text {th }}$ century. As a result, we can locate the first Lviv mill on the micro-level of the contemporary Lviv map, whereby

24 Ell-medieval and early modern measure of length. 


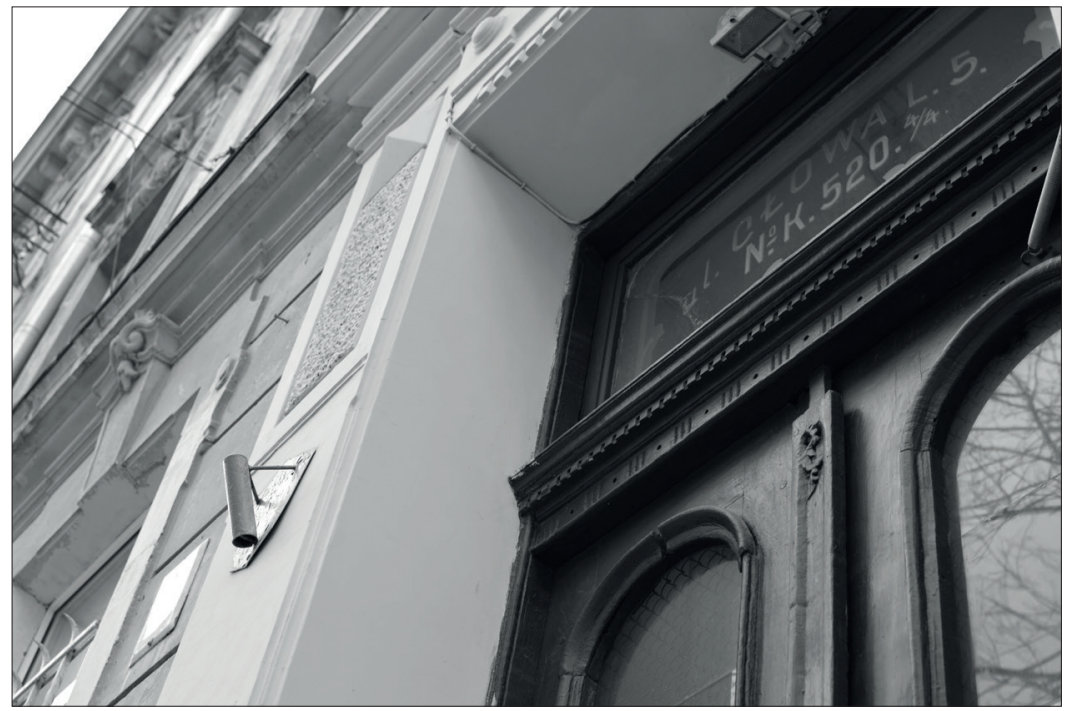

Fig. 1. Early $20^{\text {th }}$ century Lviv's signboard with both - the conscription number and the name of the street (photo by M. Dolynska)

the current address location would be 2 Khimichna str. (fig. 2).

To explain this method exactly, it is necessary to identify two points: the Early Modern "traditional" household names and street names (hodonymy) of Lviv.

The unit of the real estate was parcelaa narrow, rectangular plot. To set the tax rate, a clerk had to know how to describe the place of the household, so those places were given their own names, which changed over time. The real estate had the same names as their owners, and they are found in the data from the Early Modern era (household rent registers, purchase-sale acts, inventories of heritage, and inventories of immovable property). The houses (domus or, sometimes, lapidea) were entered under the Christian or diminutive name of the master or mistress. A unified form to indicate an owner and a concrete place of household was absent.

In some cases, the name of the master and the name of the town location or district are present, while in other cases the names of neighbourhood owners is purely additional. Lviv townsmen's surnames appeared and were confirmed during the $17^{\text {th }}-18^{\text {th }}$ centuries. Since the late $17^{\text {th }}$ century real estate was named after an owner's surname. Lviv's real estate names were confirmed and were not changed in the event of new owners. There were such real estate names as Balabanivska lapidea (from the surname: Balaban), lapidea Jukhnovska (from the surname: Jukhnovich), and lapidea Wolw-Shulcovychiviv. The household names with the surname of the contemporary owner were entered in the smaller town registers. For example, "domus Chweska de Olesice [...]"; "domus Iwan Architector [...]"26 (Zhowkva, 1613 year); "niewierna matka Berkowa, mając dom z gruntem między [...]"; "[...] uczciwy Zarudacki, mając domek z gruntem na przedmieściu Lwowskim [...]"27 (Zhovkva, 1790 year); "[...] domus Joanne Balabaszczuk"; "mediatis domus et fundi Eidel Stelner" ${ }^{28}$ (Kuty, 1813 year.) Some households were named after their

25 Центральний державний історичний архів України у Львові [hereafter: ЦЦДІА], ф. 52 (Магістрат міста Львова), оп. 2, спр. 813, f. 26-27, 48-51.

26 Central Archive of Old Records, Czołowski Records, sign. 399, p. 8, 87.

27 Наукова бібліотека Національного університету ім. І. Франка - Відділ рукописів, ф. 628.III, спр. 28, f. 1v, 4.

28 ЦДІА, ф. 81 (Магістрат міста Кути), оп. 1, спр. 1. f. 4v, 16v. 


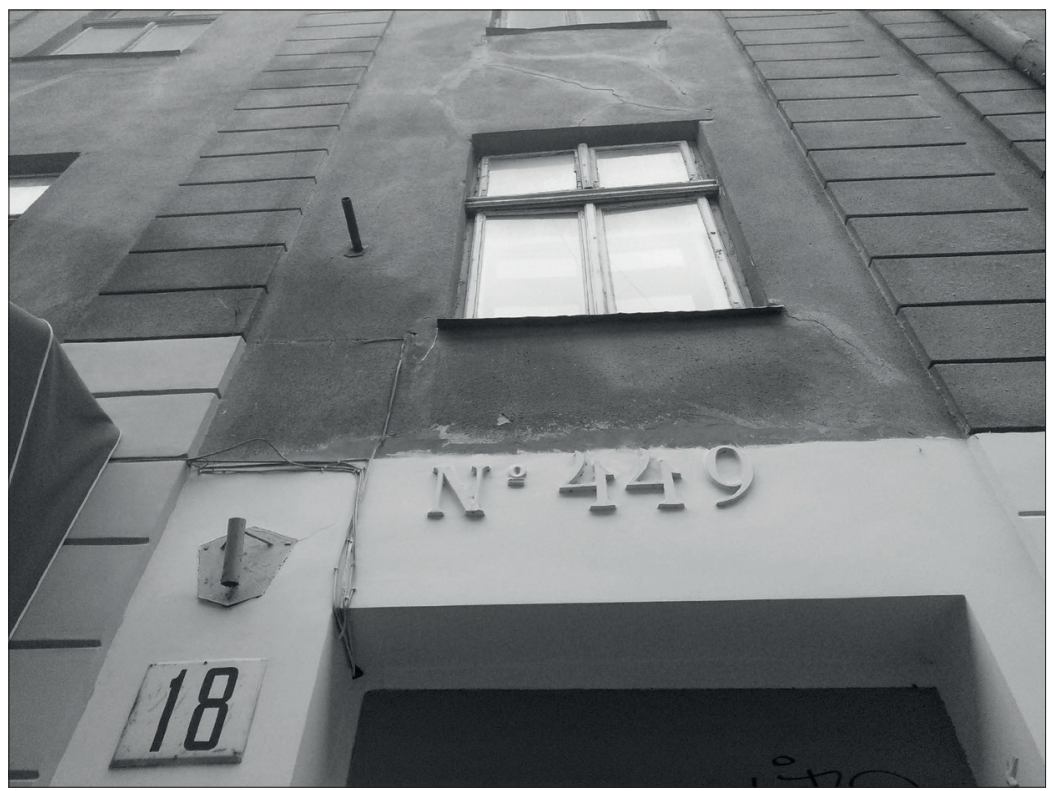

Fig. 2. $19^{\text {th }}$ century former suburb Lviv's house with the the conscription number (photo by M. Dolynska)

place in the town or after their decoration, as, for example, the house Kryve $k^{2}{ }^{29}$ ('curved circle'), which stood at the crossing with a street by the same name.

The new order of marking real estate was introduced by the Austrian officials after 1772, among other reforms. The new order of the conscription numbering was ascribed to the buildings. The new rule created special registers (cadastre) for land, ground, households and owners. Lviv's real estates received official conscription numbers in the late $18^{\text {th }}$ and early $19^{\text {th }}$ centuries. It was done through ordinal numbering, beginning with the buildings in the middle of Rynok square (the town hall and buildings near it). The household numbers were ordered along a perimeter of blocks, similar to the notes from older registers (shos). Some changes were made in the early $19^{\text {th }}$ century (fig. 2).

The contemporary system of household numeration was arranged after Lviv received the city autonomy on October

29 ЦцД|А, ф. 52. оп. 1, спр. 752, f. 12. $14^{\text {th }}, 1870$. This system of marking real estate was called the "orientation numeration". The main house of a household was the initial unit in a line of houses on a street. There are even numbers along the right line of houses and odd ones along the left line, with the start of the numeration beginning with the property closest to the Rynok square.

Much of the Lviv city government (magistrate) data contained both systems of numeration (conscription and orientation) until the First World War (fig. 1). Some examples of conscription numeration present on the historical maps of the 1920 s and 1930s, especially in the cases of copies of older cadastral maps. However, the officials in charge of the maps did not understand what the numeration systems meant, and sometimes confused ordinal enumeration with conscription numeration. The system of the orientation numeration exists to this day, with the exception of the dwellings from the Soviet period, where no coherent system was used. 
Household names or street numbers have their own long and interesting history. The name given for this type of research is hodonymy. Historians think that during the Late Medieval Age and Early Modern Era (14 $4^{\text {th }}-18^{\text {th }}$ centuries) Lviv's area of the "town within the walls" was composed of the Rynok square, eight streets and a block of dwellings in the middle of the Rynok square.

Two conditions are necessary to mention before researching Lviv's street names. Firstly, until 1871 street names were not judicially approved; street names had only traditional conditions of life. Secondly, it seems that the early term Platea is different from the contemporary term street. It meant one or several blocks (rather, a totality of a number of households) which had some unit attributes ${ }^{30}$. The origins for the street names lay in different factors such as the professions of the citizens there (Shevska, Pekarska); their ethnicity and religion (Virmenska, Ruska, Zhydivska ${ }^{31}$ ); the directions to some localities (Krakivska, Halycka); or a characteristic of an institution or a function of a dwelling (Shpytalna, Bahati kramy) ${ }^{32}$. The name of Bahati kramy can be explained neither as a street nor as a city area, because this was a group of houses in the middle of the Rynok square to the north of the town-hall. Real estates had traditional names in the official data of that time.

Much data (including cadastral maps) from the first half of the $19^{\text {th }}$ century, when Lviv was under the rule of the Austrian Monarchy, had fixed street names in the downtown sector and the former suburbs. Only during that time did suburbs receive the status of city districts.

30 М. Долинська, Історична топографія, р. 182-205.

31 As compared with: A. Janeczek, Ulice etniczne w miastach Rusi Czerwonejw XIV-XVI wieku, "Kwartalnik Historii Kultury Materialnej", 1-2, 1999, p. 131-147.

32 As compared with: A. Wyrobisz, Nazwy ulic, placów i dzielnic w miastach polskich: nośniki informacji - źródła historyczne - zabytki kultury, "Przegląd Historyczny", 90, 1999, p. 511-523.
Yet, street and square names were awarded the judicial status only once Lviv received an autonomous status. The hodonymic units were officially regulated; new names were given to the streets and squares, while houses were assigned the above-mentioned orientation numeration. The practical realisation of the reform manifested itself in sign boards containing orientation numbers and names of the street, road or square, which subsequently appeared on each house in Lviv. In the case of a house with several facades, a different name and number was placed on the signboard of each one. The names of streets and squares were written on additional, larger signboards, which had a different shape and colour. Signboards of rectangular form were placed in radial streets, and oval ones adorned cross streets. The letters and figures on the signboards of squares were red, while those on street signs were black. Additionally, there was a difference in the colours of the borders of city districts: red for downtown; red-brown for the First (Halycka) district, green for the Second, (Krakivska) yellow for the Third (Zhovkivska); blue for the Fourth (Lychakivska) ${ }^{33}$.

Though the system of orientation numeration still exists in Lviv today, street names have been completely changed approximately six times through different regulations.

Therefore, comparing $20^{\text {th }}$ century street names (including the building number), the Austrian conscription numeration and traditional Early Modern real estate names, a scholar can precisely locate $16^{\text {th }}-$ $17^{\text {th }}$ century households. For example, the contemporary address of 11, Ivana Fedorova Street had the first orientation address of Blacharska 11, and conscription number $190 \mathrm{~m}$; it also had the initial conscription number 183 . In the late 1860 s, it was

\footnotetext{
33 F. Barański, Wprowadzenie, in: idem, Przewodnik po Lwowie, Lwów 1902, p. 7.
} 
named "lapidea Teodozy"; from the 1750s - c. 1800s the household's name retrospectively changed from Paparowska to Tomkiewiczowska, and then to Łangiszowska. In the middle of the $17^{\text {th }}$ century, the owner of the household was Habriel Łangisz ${ }^{34}$.

\section{Cartography}

The last example concerns a house located "inter muros" (in downtown of Lviv). In the same way as previously described, one can establish the households within the suburbs, especially palaces, churches, mills, large land-estates, etc. Those objects can be precisely located on both a contemporary and an old map. The $16^{\text {th }}-18^{\text {th }}$ century records are often divided into chapters with titles. Some of these titles signify the streets, places or settlement names, others describe the direction of clerk traffic. By drawing some exact object, which was included to one of these streets or places by the clerk, the researcher receives a clear picture of its spatial location. This location can then be correlated with $18^{\text {th }}-19^{\text {th }}$ century maps, which are available to compare with the resulting sketches.

Furthermore, Czech scholars have obtained exemplary results from their studies of $18^{\text {th }}-19^{\text {th }}$ century cartography. They introduced it into the branch of historical geography ${ }^{35}$, and stated that there are two directions: geographical science and spatial historical science ${ }^{36}$. The historical phenomenon of drawing on the map is the cartographical method in history ${ }^{37}$. With this method, it is possible to subsequently establish a picture of the place in the space and analyse the correlations.

\footnotetext{
34 M. Dolynska, Preservation Preproject Reaserch Based on Social \& Topographical Testimonial (paper presented at the International Conference on Conservation, Kraków, October 23-26, 2000).

35 0. Kudrnovská, Josefské mapování Českých zemí a jeho topografický popis (s rozborem popisu pražské sekce), "Historická geografie", 24, 1985 , p. 55

36 E. Semotanová, Kam směřuje naše historická geografie?, “Historická geografie", 28, 1995, p. 11-12.

37 J. Kašpar, Geografická metoda, p. 218.
}

Austrian maps of cities, towns and villages are very useful for social analyses due to the substantial information available in such sources. These maps (land cadastration) are similar to those of the Italian, Czech, Slovak, Hungarian, Rumanian, Polish, Ukrainian and Austrian lands that were part of the Austrian Monarchy and later of the Austrian-Hungary Empire until the early $20^{\text {th }}$ century.

By considering as an example the part of Ukraine known as Galicia, it is possible to examine this methodology further. Land cadastral maps appeared in Galicia during 1820s-1850s ${ }^{38}$. The maps are in two scales: $1: 1440$ and 1:2880.

The boundaries of every household are fixed for the purpose of establishing a ground inventory. Private brick or stone buildings are drawn in a bright red colour; whereas churches, cloisters, state and public buildings are rendered in a dark red colour. There are red and black numbers written on the map. Red numbers are the ordinal numeral of the map, and the same figure can be read in the registers attached to each of the cadastral maps. There are manuscript registers for cadastral maps covering almost all of Galicia's towns and cities at the Lviv Historical Archive, which provides the possibility of comparing the conscription number of a household fixed in the register and its location drawn on the map.

Earlier maps of the Austrian Monarchy (Jozefinische Mappe) were completed, between the 1760s and the 1780s. The map was created for military purposes in case of a war ${ }^{39}$, which is why the features of landscape were drawn so precisely. It has been claimed that Austrian spies stole the majority of secret Prussian maps and only after that did Austria begin to develop its own accurate military

\footnotetext{
38 ЦЦДІА, ф. 186, оп. 1, спр. 3486.

39 K. Kuča, Města a městečka v Čechăch na Moravě a ve Slezku, Praha 1996, p. 318.
} 
cartography ${ }^{40}$. The next step of similar land registration was carried out during the first half of the $19^{\text {th }}$ century and was named the Franciscan cadastration (registration) of the lands (Franiskanische Mappe).

A large group of engineers performed sketches of all cities, towns, villages, and other plots (such as fields, pastures and forests), as well as rivers, roads, etc. The Josephine maps of the Eastern part of the Monarchy, Western Ukrainian Land (Galicia and a part of Bukowyna - Königsreich Galizien und Lodomerien) were dated $1779-1783^{41}$, and are referred to as von Mieg's maps. All the parts of these maps are in the Vienna Military Archive. One sheet is a piece of carton-paper with colour, manuscript drawing, and the scale is $1: 28,800^{42}$ (fig. 3). The later Franciscan cadastral map had the same division and the same scale (fig. 4).

It is more exact, like the contemporary topographical map. For example, the sketch of the little town named Kuty is in the lower part of both sheets. There is a written date " 1830 " on the sheet with Kuty of the Franciscan map and there are remarks about some elaborations, made more precisely in $1863^{43}$. The result of the comparison of both maps with the Josephine Cadastre is three schemes of the topography of the real estates of 1715,1765 and $1785^{44}$ (fig. 5-7). All parts of those maps are available online at the website Arcanum. There are two layers online: the contemporary map and the layer of the map of one of the historical maps, for example, the first military survey. The paper version of von Mieg's map (Galicja

40 R. Eysymontt, The Historical Layers of the Lower Silesia Towns - the Investigations based on the Historical Cartography, "Geology, Geophysics \& Environment", 39, 2013, p. 85.

41 Г. Петришин, Карта фон Міга як джерело до містознавства Галичини, in: Картографія та історія України. 3б. наук. Праць, ред. Я. Дашкевич et al., Львів-Київ-Нью-Йорк 2000, р. 55

42 Kriegsarchiv, Kartensammlung, BIXa, 390 (Jozefinische), Section \# 20.

43 Ibidem, BIX, 390 (Franziskanische), Section \# 20 oesteliche Collone \# 17.

44 М. Долинська, Теоретична реконструкція, р. 15-44. na józefinskiej mapie topograficznej 17791783) edited by Polish scholars Zdzisław Noga, Waldemar Bukowski, Bogusław Dybaś is currently under elaboration.

The Josephine Cadastre and the map of the Josephine Land's cadastration do not correlate with each other, though there are no common numbers or other marks in two documents (the manuscript and the map). That is why this stage of work was very time consuming. In volume number 1 of the Ukrainian historical towns' atlas, Lviv, there are 25 maps or fragments of maps of Lviv, including von Mieg's map and the central part of the Lviv cadastral map.

\section{Iconography}

The worst situation for a researcher is to be found when working with iconography sources. There are numerous views and panoramas of towns in different archives, libraries, museums and private collections. However, they are not easy to classify, so finding or locating them is often done by chance. Similar problems are encountered with designs and sketches of buildings from the late $18^{\text {th }}$-early $20^{\text {th }}$ centuries. In the case of the Austrian Monarchy's real estate, the owner had to submit a sketch of a proposed new building or of the desired alterations to an existing building. The majority of sketches were burned during the Lviv town hall fire of 1848. Rare copies are available, allowing an insight into the appearance of houses and thus they may be useful for 3D mapping.

\section{Urbanonymy}

The next key element of the research is urbanonymy. In addition to the importance of street names, there are numerous other places which have their own names in every city, town or village (such as a square, park, cemetery, hill or mountain, river or stream or sea or ocean, forest or bush, settlement or block, field or garden, etc). Urbanonymy is a part of toponymy and, at the same time, 


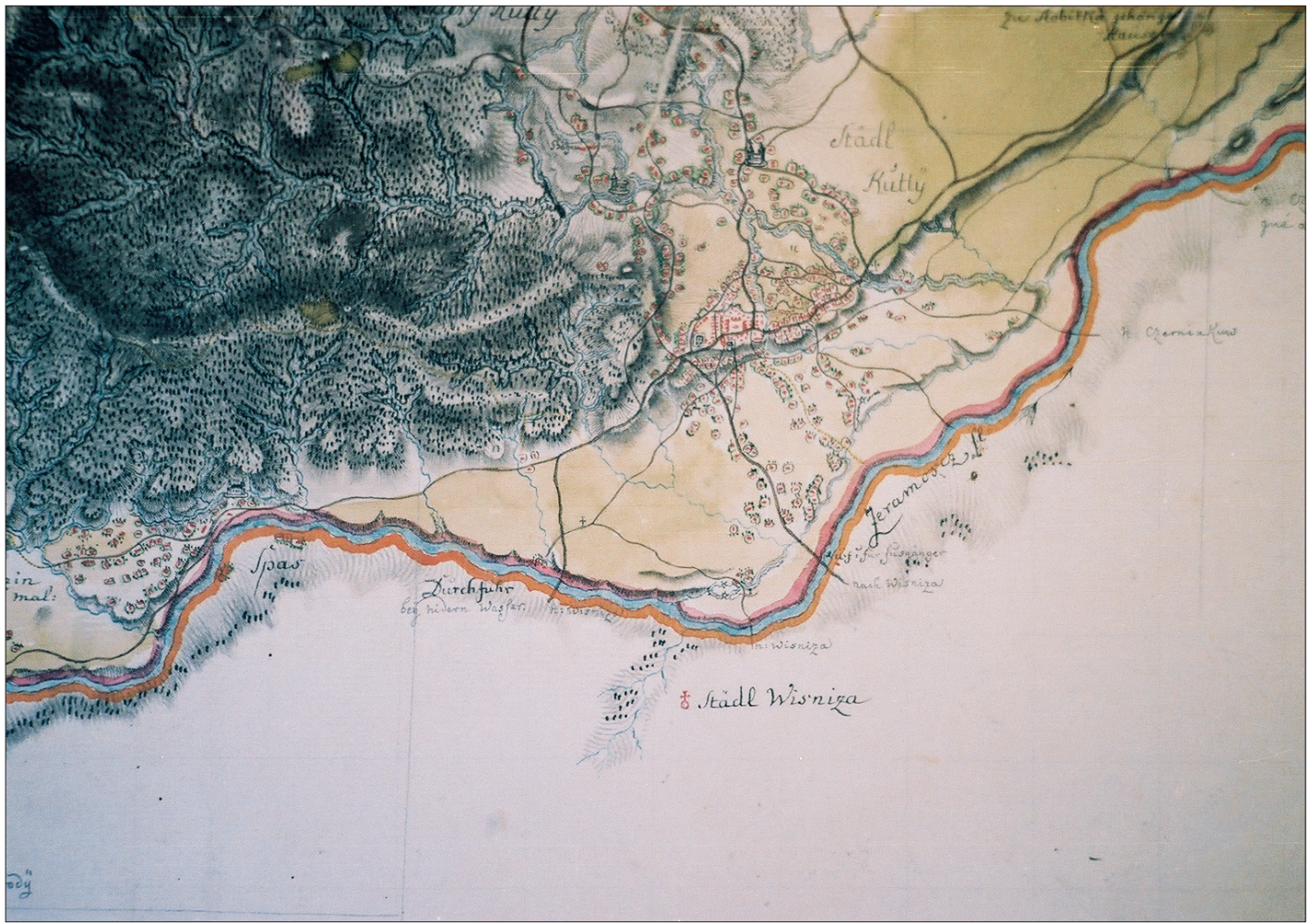

Fig. 3. The fragment of the Jozefin map of the town Kuty.

(c) Österreichisches Staatsarchiv 2014, (c) Arcanum Adatbázis Kft, 2014

it is an area of linguistic, geographical and historical research.

Furthermore, toponyms are valuable in the research of ethnology and archeology, as well as play an important role in historical geography.

Each of the sciences has its own tasks and methods. They have different views of toponymy and different methods and ways of classification ${ }^{45}$. The Polish historian Przemyslaw Tyszka insists that the variants of the street name and its reception be immutable ${ }^{46}$. The Ukrainian scholar

45 В.В. Денисюк, Антропонімія українських історіограффічних пам'яток другої половини XVII-XVIII ст., Київ 2003 (a summary of professional accomplishments for the doctoral dissertation); A. Wyrobisz, Nazwy, p. 511-523; О.Є. Афанасьєв, Географфінне дослідження топонімічної системи України, Київ 2006 (a summary of professional accomplishments for the doctoral dissertation); Н.В. Подольская, Словарь русской ономастической терминологии, Москва 1978, р. 7-15, 27, 50, 154, 160-161.

46 P. Tyszka, Obraz przestrzeni miejskiej Krakowa XIV-XV wieku w świadomości jego mieszkańców, Lublin 2001, p. 133, 136.

Yaroslav Dashkievych affirmed that historical urbanonymy does not have constant methods of research and often uses "the toponymycal primitive" methods - the etymologization of names ${ }^{47}$.

The research methodology applied to studying these scientific works consisted of selecting the criteria for researching the urbanonyms through different science branches: linguistic, geographical, and historical ones. The research of this data indicates several conclusions:

1. It is very important that each proper name consists of a proper noun and a denotation, denotation being the general name of an object ${ }^{48}$. For example, Warsaw is the proper name and the city is the denotation.

\footnotetext{
47 Я.Р. Дашкевич, Навколо історичного атласу України, "Україна в минулому", 1, 1993, р. 208; idem, Виникнення міст України: міфи та реальність, "Український історичний журнал", 2, 1992, р. 8.
}

48 K. Handke, Dzieje Warszawy nazwami pisane, Warszawa 2011, p. 28. 


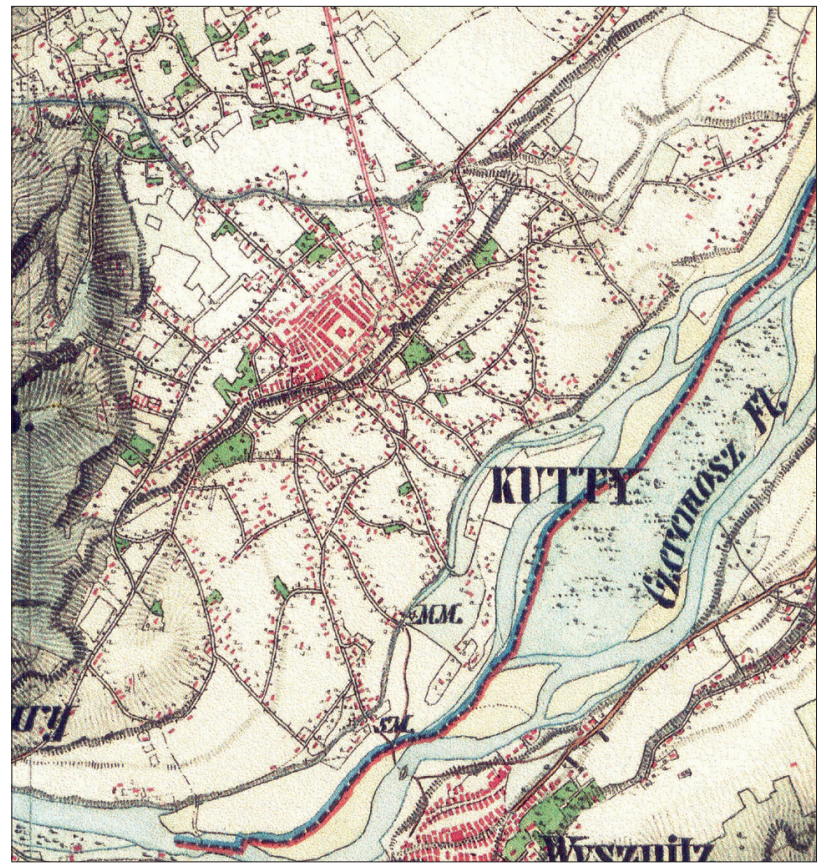

Fig. 4. The fragment of the Franziskan map of the town Kuty.

(c) Osterreichisches Staatsarchiv 2014,

(C) Arcanum Adatbázis Kft, 2014

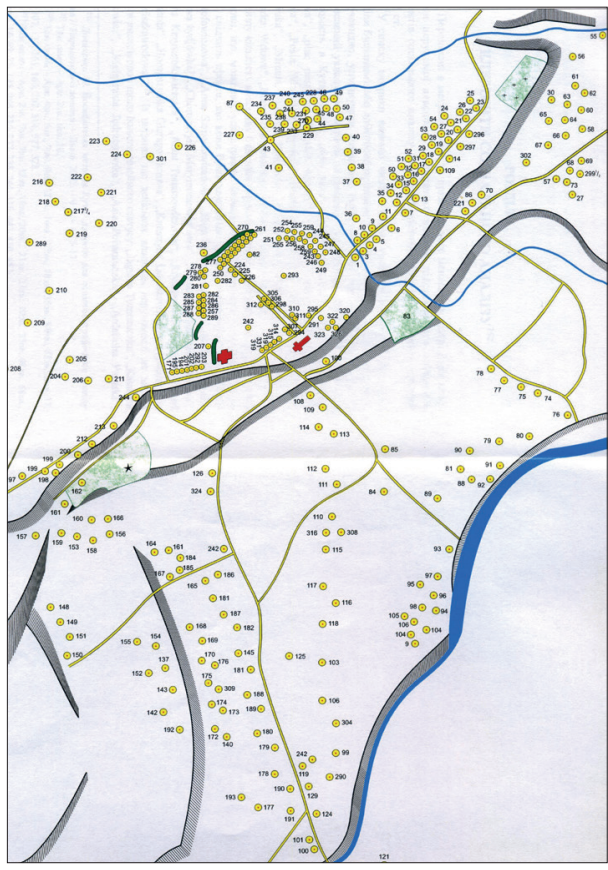

Fig. 6. The hypothetical scheme of the topography of the households with their conscription numbers of the town Kuty of the 1765 year

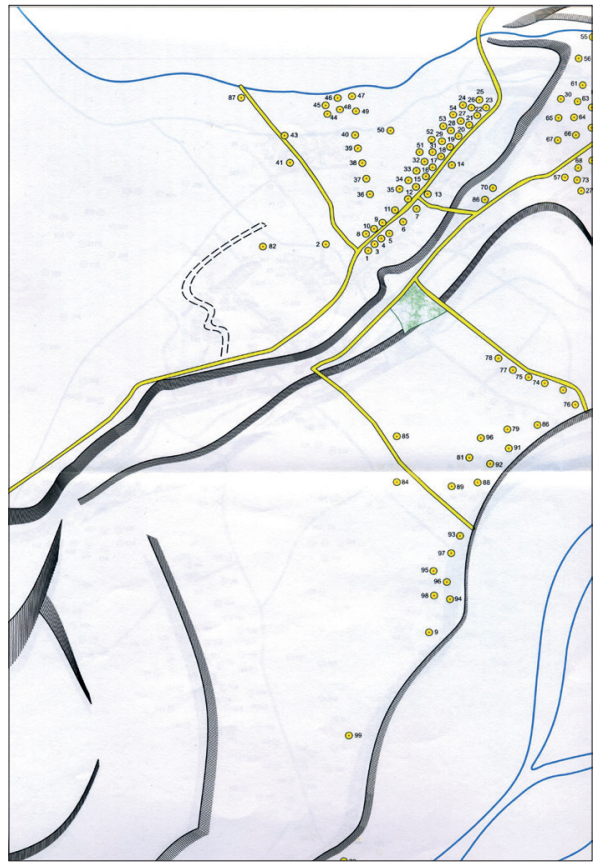

Fig. 5. The hypothetical scheme of the topography of the households with their conscription numbers of the town Kuty of the 1715 year

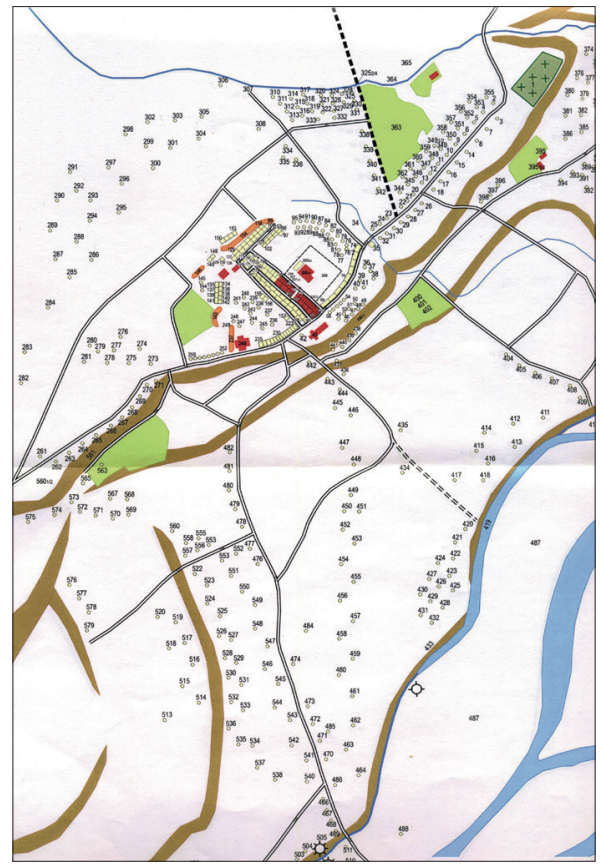

Fig. 7. The hypothetical scheme of the topography of the households with their conscription numbers of the town Kuty of the 1785 year 
2. Irradiation of name meanings, the proper noun of the name was passed from one object to another. There are many examples of such transition in Early Modern Lviv: from the suburban settlement to the road (Lychakiv/Lychakivska), from the church to the place (Sofiivka), from the road to the park (Stryiska/Stryskyy), from the castle to the hill (Vysokyy zamok the High Castle $)^{49}$.

3. Transformation of the denotation to the proper noun of the name. In the $17^{\text {th }}-18^{\text {th }}$ centuries the word vulka was a synonym for the word settlement, while later, in many cases, the word vulka was transformed to the proper name ${ }^{50}$.

4. The unclear notion. The name of places often described a territory without exact borders ${ }^{51}$.

5. There are official and traditional names of places in a town or city. The traditional names have existed for centuries. The official names were given by the executive body (namely, by the town-hall of Lviv in 1871). The traditional names describe the place with references to nearby locations, communications, buildings or natural features; they have an exclusively informative function without any legal significance.

One of the subcategories of the traditional toponyms (and, at the same time, of the traditional urbanonyms) are the horonyms. Horonyms describe non-linear structures (territories) and were used to name any place within the town's boundary, except for streets or squares. Horonyms do not provide information about the official administrative division of the time, but they use traditional names.

To understand how long horonyms of the city's names have lasted, it is necessary to focus the research on a retrospective comparison of the pre-statistical sources.

49 М. Долинська, Історична топографія, р. 23, 81, 173-175, 182, 227, 237.

50 Eadem, Історична топографія, р. 90, 136-137, 152, 154, 173-175, $201,216$.

51 Ibidem, p. 91, 141, 169, 178-179, 181-182, 202, 283, 285.
The contemporary vocabulary of Lviv's dialect (Leksykon lvivskyy povazhno I na zhart) ${ }^{52}$ contains sixty-five fixed horonyms of Lviv's area which are currently being used by city dwellers. This was used as the foundation for the retrospective method of analysing horonyms in Lviv. This data was compared with the following sources: late $19^{\text {th }}$ century to early $20^{\text {th }}$ century guidebooks $s^{53}$ and mid- $19^{\text {th }}$ century maps, with their attached registers ${ }^{54}$.

The administrative unit division of Lviv's territory was applied in the research ${ }^{55}$, because in the period 1772-1918 Lviv was a part of the Austro-Hungarian Empire. That is why the following four groups of horonyms were excluded:

1. The names of former city villages that are currently preserved as the city's horonyms, because those villages were absorbed into the city only during the $20^{\text {th }}$ century (today names of those former villages do not reflect the administrative division).

2. The village of Sygnivka, which was founded only in the 1820s in the area of the former suburb Halytskie of Lviv's Early Modern period.

3. The names of villages which surrounded the town, but were not under the rule of the town hall.

4. All the names of natural and manmade objects which were found within these villages.

Thus, after this exclusion, we have forty-eight names (horonyms). The analysis

52 H. Хобзей et al., Лексикон львівський поважно і на жарт, Львів 2009 , p. 58, 60, 69, 82, 85-88, 115, 139, 156, 163, 215, 227, 231, 251, 266, 270, 277, 281, 289, 303, 305-309, 317, 321, 326, 331, 355, 363, 390, $415,417,433,438-439,449,476,505,508,517-518,520,522,531$, $534,589,600,607,610,620,642,644,650-652$.

53 F. Barański, Przewodnik po Lwowie, Lwów 1902, p. 27-157.

54 ЦЦДІА, ф. 186 (Краєва земельна податкова комісія), оп. 1, спр. 3476; ibidem, oп. 8, спр. 630; М. Долинська, Маловідома літограффічна карта Львова першої половини XIX ст., in: Історичне картознавство. Збірник наукових праць, ред. Я. Дашкевич еt аl., Львів-Київ-Нью-Йорк 2004, p. 266-270.

55 Eadem, Функціонування хоронімів на території Львова впродовж середини XIX-початку XXI ст., "Місто: історія, культура, суспільство", 1, 2016, p. 193-198 (http://mics.org.ua/wp-content/uploads/2016/01/14. pdf, access: March 19, 2017). 
showed that one name came into being in the late $20^{\text {th }}$ century and eight others during the first half of the $20^{\text {th }}$ century. Fifteen horonyms, as well as their names were established during the $19^{\text {th }}$ century. That leaves twenty-four names which were used during the earlier period and continue being used now in the city. The research needs further investigation within a retrospective comparison of the names recorded in the Early Modern serial sources; these sources being the results of the $19^{\text {th }}-21^{\text {st }}$ century research of the names from the 1788 Josephine Cadastre and comparing them with the $14^{\text {th }}-18^{\text {th }}$ century manuscripts and published data.

The next step is research on the traditional horonyms from the Lviv territory during the $14^{\text {th }}-18^{\text {th }}$ century using the manuscript and published rent records and the names of residents. Indeed, scholars can find many names from a variety of different manuscripts, for example judicial books; however, the data is not regular or as clearly consistent leading to such results being more accidental and less methodical.

The result of the initial research shows that there were several types of names for different places in the Early Modern period of the town. All of these types have certain features, which suggests variability and difficulty.

The main result of research is the proposal to classify objects instead of classifying names. The objects of urbanonymy are natural, manmade and virtual. Natural objects are such as hills, rivers etc. Manmade features include fields, millponds, etc. Virtual object are laneos, plots, etc. Some objects are real and others are imaginary. One can divide imaginary ones into those of official and unofficial use, but with an unclear division between the two ${ }^{56}$.

56 Eadem, Напуття профессора Дашкевича щодо урбаноніміки, submitted to: Conference Міжнародна конференція Україна- Європа -Схід: Проблеми та перспективи сучасної гуманітаристики (до 90-річчя від дня народження Ярослава Дашкевича), Lviv, December, 13-14 2016.
There are six additional conclusions to note:

1. The sources have interpreted the term street as an surface object, so it is reasonable to submit them as the horonyms of the urbanonymic type.

2. The name disappeared after the object had been destroyed.

3. Most proper nouns were possessive; it was a name/surname of the owner (with the typical Slavic form) before the denotation.

4. There is a group of names without denotations.

5. Most of the Late Medieval and Early Modern names were not permanent. This means that a name changed, for example, after its owner had changed. This process referred mainly to man-made objects, but data and literature analysis show even the mountain names were changeable, with the exception of just a few ${ }^{57}$.

6. The analysis of the confirmed data shows that people of that time had their own vision/understanding of such terms as town, suburb, settlement, street, etc. There are many examples of this interpretation ${ }^{58}$.

This study of toponymy has some similar elements to the research of historical topography, which is why, hopefully, the next step should be the application of the uncovered data of Lviv city names using GIS.

\section{Conclusions}

1. The method of recreating the historical topography of urban spaces should be available to all the lands of former Austro-Hungarian Empire.

2. The method is similar to the corresponding methods and subjects of historical geography.

\footnotetext{
57 М. Долинська, М. Погорілко, З історичної топографії Львова, "Записки Наукового товариства імені Шевченка", 268, 2016, р. 122-123.

58 M. Dolynska, Przestrzenny model miasta (Lwowa) na prawie niemieckim: rzeczywistość i recepcja nowożytna, submitted to: Conference Idea miasta - model miasta. Wyobrażenia na temat miast na przestrzeni dziejów, Toruń, June 2-3, 2016.
} 
3. The result of the retrospective method in connecting the conscription numbers and the older traditional household names in the Early Modern data (especially registers of ell rent) allows to describe the historical topography of the period. Studying the Josephine topographical maps is useful for creating their hypothetical sketches.

4. The auxiliary step of the research is equally important: the analyses of the Josephine and Franciscan Cadastres of immovable private property data (with conscription numerations), cadastral registers,

\section{Bibliography}

Афанасьєв О., Географічне дослідження топонімічної системи України, Киї 2006 (PhD thesis summary).

Аашкевич Я., Виникнення міст України: міфи тареaльність, "Український історичний журнал", 2, 1992 , p. 8-13.

Аашкевич Я., Навколо історичного атласу України, “Україна в минулому", 1, 1993, р. 163-214.

Аашкевич Я., Социотопография городов как направление историко-краеведческих исследований, in: Тезисы докладов и сообщений. Первая всесоюзнал научнал конферениия по историческому краеведению, отв. реА. С.С. Хромов, Полтава 1987.

Аенисюк В., Антропоніміз украӥнських історіографічних пам'sток другої половини XVII-XVIII cm., Київ 2003 (PhD thesis summary).

Аолинська М., "Bступ до coyiomonографiі" sк узагальнений метод історико-архівних попередніх досліджень в реставрації архітектурних об єктів, "Вісник Аержавного університету » політехніка«. Архітектура”, 429, 2001, р. 166173.

Аолинська М., "Вулиці" львівських передмість у фіскальник документах останньої третини XVIII cm., “Записки НТШ. Праці секції спеціальних (Аопоміжних) історичних дисциплін”, 152, 2006, p. $98-102$.

Аолинська М., Гороніми історичних передмість Аввова кіния XVIII-початку XX ст., "Вісник $\Lambda$ ьвівського університету. Серія історична”, 3940, 2005, p. 413-429.

Аолинська М., Гороніми на територіях колишніх міських сіл Аьвова, “Арогобицький краєзнавчий збірник”, 8, 2004, р 229-235. and late $19^{\text {th }}$ century guide-books in chronological order. The comparison of the results thus obtained with the Josephine topography maps and the cadastral maps allows to locate real estate on the level of the contemporary address.

5. The author's suggestion to classify objects rather than to classify names (traditional urbanonyms) brings the study of the historical topography and that of the historical urbanonymy closer to each other. The next step should consist of applying the obtained data on city names using GIS.
Аолинська М., Ао проблеми складових та джерел coyiomonoгpaфii, “Арогобицький краєзнавчий збірник”, 7, 2003, р. 420-433.

Аолинська М., Елементи картографічного методу дослідження у вступі до сочіотопографіï, in: Icmoричне картознавство України. Збірник наукових пращь, реА. Я. Аашкевич et al., Аьвів-КиївНью-Йорк 2004, p. 44-55.

Аолинська М., Елементи локації Аввова у княжу добу, “Записки НТШ. Праці комісії архітектури і містобудування”, 255, 2008, р. 78-85.

Аолинська М., Iсторична топографія Аввова XIVXIX cm., Аьвів 2006.

Аолинська М., Історична топографія нерухомої власності містечка Кути (основні точки, шиях обходу), “Народознавчі зошити”, 1-2, 2004 , p. 563-581.

Аолинська М., Історична топографіз самоврядних передмість міста Аьвова XVI-XVIII cm., "Арогобицький краєзнавчий збірник”, 9, 2004, р. 214 224.

Аолинська М., Йосифінська метрика, як джерело дяя вивчення території львівських передмість,

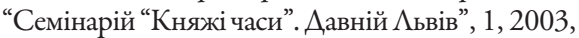
p 47-54.

Аолинська М., Аьвів: простір на тлі мешканців XIII-XIX cm., Аьвів 2015.

Аолинська М., Маловідома літографічна карта Аввова першої половини XIX cm., in: Iсторичне картознавство: Збірник наукових пращь, реА. Я. Аашкевич et al., Аьвів-Київ-Нью-Йорк 2004, p. 266-270.

Аолинська М., Напутms професора Аашкевича щолдо урбаноніміки, submitted to: Conference 
Міжнародна конференція Україна - Європа Схід: Проблеми таперспективису часної гуманітаристики (до 90-річия від дня народження Ярослава Аашкевича), Lviv, December, 13-14, 2016.

Аолинська М., Нерухомість німецької родини Штехерів в пізньосередньовічному Аввові: традиційний та інтердисциплінарний погляд, Матеріали міжнародної наукової конферениї Феномен мультикультурності в історії України і Польщі, Харків 2016, p. 87-93.

Аолинська М., Пам'ятник Королю Аанилу в контексті історичної топографії Аввова, “Пам'ятки України”, 1, 2005, р. 132-139.

Аолинська М., Ретроспективна метода дослідження забудови середмістя Аввова, in: Урбаністично-архітектурні проблеми міст Галичини. Збірник наукових праць, реА. Г. Петришин еt al., Аьвів 1998, p. 56-62.

Аолинська М., Cоціотопографічна характеристика Української (Руської) дільниці Аьвова у XVIXVIII cm. Загальні уваги, in: Ао джерел. Збірник наукових праць на пошану Олега Купчинського 3 нагоди його 70-річия, т. 1, реА. I. Гирич et al., Київ-Аьвів 2004, р. 766-780.

Аолинська М., Теоретична реконструкція історичної топографії містечка (на прикладі смт. Кути), Аьвів 2007.

Аолинська М., Формування і розвиток територіі Аввова: зміни адміністративно-територіального nodisy мiсmа в XIII-XXI cmosimmsx, in: Аввiв: місто - суспільство - культура: Збірник наукових праць, ред. О. Аркуша, О. Вінниченко,

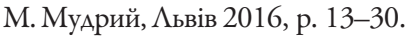

Аолинська М., Функціонування хоронімів на територіі Аввова впродовж середини XIX-початку XXI cm., "Місто: історія, культура, суспільство", 1, 2016, p. 191-206 (http://mics.org.ua/wp-content/uploads/2016/01/14.pdf, access: March 19, 2017).

Аолинська М., Мемьник О., Методика використання журналів обліку XIX cm. для локалізаціі нерухомості в Галичині, "Вісник Національного університету » $ь$ ьвівська політехніка «. Архітектура", 410, 2000, р. 362-363.

Аолинська М., Погорілко М., 3 історичної топографії Аввова, “Записки наукового товариства імені Шевченка”, 268, 2016, p. 107-128.

Йосифінська (1785-1788) і францисканська (18191820) метрики. Першіпоземельні кадастри Галичини. Покажчик населених пунктів, реА. П. Захарчишина, Київ 1965.

Капраль М., Аолинська М., Процес локауії міста Аввова на магдебурзвкому праві у XIII-XIV cm., in: Amлас українських історичних міст. Аввів, ред. М. Капраль, Київ 2014.
Петришин Г., Карта фон Міга sк джерело до містознавства Галичини, in: Картографія та історія Украйни. 3б. наук. праць, реА. Я. Аашкевич et al., Аьвів-Київ-Нью-Йорк 2000, p. 54-79.

Подольская Н., Словарь русской ономастической терминологии, Москва 1978.

Хобзей Н. et al., Аексикон львівський поважно і на жарт, Аьвів 2009.

Barański F., Przewodnik po Lwowie, Lwów 1902.

Czacharowski A., Sociotopography of Medieval and Late-Medieval Towns in the North-European Zone as Exampifield by Torun, "Acta Poloniae Historica", 34, 1976, p. 121-129.

Czacharowski A., Zagadnienia socjotopograficzne póżnośredniowiecznego Torunia, in: Miasta doby feudalnej w Europie Środkowo-Wschodniej. Przemiany spoteczne a uktady przestrzenne, red. A. Gieysztor, T. Rosłanowski, p. 137-146, Warszawa-Poznań-Toruń 1976.

Czacharowski A., Ze studiów nad struktura spoteczna mieszczaństwa toruńskiego na przetomie XIVIXV w., "Acta Universitatis Nicolai Copernici. Nauki humanistyczno-Społeczne. Historia”, 9, 1973, p. 89-97.

Czaja R., Socjotopografia miasta Elblaga w średniowieczu, Toruń 1992.

Dolynska M., Preservation Preproject Reaserch Based on Social \& Topographical Testimonial (paper presented at the International Conference on Conservation, Kraków, October 23-26, 2000).

Dolynska M., Przestrzenny model miasta (Lwowa) na prawie niemieckim: rzeczywistość $i$ recepcja nowożytna, submitted to: Conference Idea miasta - model miasta. Wyobrażenia na temat miast na przestrzeni dziejów, Toruń, June 2-3, 2016.

Eysymontt R., The Historical Layers of the Lower Silesia Towns - The Investigations Based on the Historical Cartography, "Geology, Geophysics \& Environment”, 2, 2013, p. 81-93.

Goliński M., Socjotopografia późnośredniowiecznego Wrocławia, "Acta Universitatis Wratislaviensis. Historia", 134, 1997, p. 3-540.

Handke K., Dzieje Warszawy nazwami pisane, Warszawa 2011.

Janeczek A., Ulice etniczne w miastach Rusi Czerwonej w XIV-XVI wieku, "Kwartalnik Historii Kultury Materialnej", 1-2, 1999, p. 131-147.

Jasiński T., Próba nowego spojrzenia na toruńskie księgi szosu, in: Studia nad dziejami miast i mieszczaństwa $w$ średniowieczu, t. 2, Toruń 1996 (Studia Polonica Historiae Urbanae, 2), p. 133-139.

Kašpar J., Geografická metoda a kartografická metoda $v$ historikově práci (Príspèvek terminologický), "Historická geografie”, 24, 1985, p. 214-218.

Klonder A. (rev.), Helga Schultz, Berlin 1650-1800. Sozialgeschichte einer Residenz, "Kwartalnik Historii Kultury Materialnej”, 1, 1991, p. 63-71. 
Kuča K., Mèsta a městečka v Čechăch na Moravě a ve Slezku, Praha 1996.

Kudronovská O., Josefské mapováni českych zemi a jeho topografický popis (s rozborem popisu pražskésekce), "Historická geografie", 24, 1985, p. 55-103.

Semotanová E., Kam směruje naše historická geografie?, "Historická geografie", 28, 1995, p. 11-15.

Sowina U., Najstarsze sieradzkie testamenty mieszczańskie z początku XVI wieku. Analiza źródtoznawcza, "Kwartalnik Historii Kultury Materialnej", 1, 1991, p. 3-25.

Tomczak A., Źródta kartograficzne do dziejów Torunia z przetomu XVIII i XIX w., "Acta Universitatis Nicolai Copernici. Nauki Humanistyczno-Społeczne. Historia”, 9, 1973, p. 175-179.
Tyszka P., Obraz przestrzeni miejskiej Krakowa XIV-XV wieku w świadomości jego mieszkańców, Lublin 2001.

Wiesiołowski J., Poznański katalog rajców dożywotnych z poczatku wieku XVI, in: Homines et societas. Czasy Piastów i Jagiellonów, red. J. Bieniak et al., Poznań 1997 (Prace Komisji Historycznej, 55), p. 513-519.

Wiesiołowski J., Socjotopografia późnośredniowiecznego Poznania, Poznań 1997.

Wiesiołowski J., Sołacz średniowieczny i staropolski, "Kronika Miasta Poznania", 3, 1999, p. 27-52.

Wyrobisz A., Nazwy ulic, placów i dzielnic w miastach polskich: nośniki informacji - źródta historyczne zabytki kultury, "Przegląd Historyczny", 90, 1999 , p. 511-523.

\section{Summary}

Studying the historical urban topography requires addressing the maps and city plans from a particular time period. Due to the fact that the city plans of the locations, in what is present-day western Ukraine, only begun being developed in the $17^{\text {th }}$ and $18^{\text {th }}$ century, a need to formulate a method of creating reconstruction maps for the previous periods of time has emerged. Such a method is based on retrospective comparisons of the written sources with the cartographic, iconographic, toponimic (urbanonimic), and archaeological ones. The following article tackles the problem of reconstructing historical topography using the retrospective method in the case of Lviv and other, smaller towns in the region. The historical topography and its methods are closely connected with historical geography and methodology implemented therein. Both fields aim to illustrate historical events on the map, which allows for depictions of the cultural landscape. The

most important sources, fundamental for the research presented, are the Josephine topographical maps of Galicia and Josephine Land's cadastration comprising the registers of all the $18^{\text {th }}$ century properties. Their comparison with the earlier sources enables, to some extent, the identification of settlements, built-up areas, and elements of the landscape dating back to the Modern Period, or even the late Middle Ages, while contrasting them with both the Franciscan Cadastre and the $19^{\text {th }}$ and $20^{\text {th }}$ century indexes allows for the location of the current addresses. It is worth mentioning that, in such studies, the cartographical sources are indispensable, the iconographic ones are of a secondary, ancillary role, and the urbanonimic sources are of the greatest value. The method presented can be applied to the historical-topographical analyses of the cities of the whole former Austrian and Austro-Hungarian Empire.

Keywords: historical topography, hypothetical map, Josephine and Franciscan Cadastres of immovable private property, Josephine topographic map, conscription number, historical urbanonymy, denotat

Maryana Dolynska - Department of Classical, Byzantine and Medieval Studies, Ukrainian Catholic University, Lviv, Ukraine (e-mail:mardol@ucu.edu.ua) 